\title{
SELEKSI PENGANGKATAN HAKIM DALAM SISTEM PERADILAN INDONESIA: KAJIAN PUTUSAN MAHKAMAH KONSTITUSI NOMOR 43/PUU-XII/2015
}

\author{
Meylin Sihaloho \\ Fakultas Hukum Universitas Katolik Parahyangan \\ E-mail: meylin.haloho@gmail.com
}

\begin{abstract}
This research has the purpose to explain the selection for appointment of judges in the judicial system of Indonesia that is reviewed based on the decision of the Constitutional Court Number 43/PUU-XII/2015. This research uses normative juridical approach with specific research based on descriptive analysis. Judges have an important role in the judicial system in Indonesia, it is expected that the selection for appointment of judges is conducted by authorized state institutions, in accordance to the legislation in force in order to guarantee the independence of judiciary and the independence of judges. This research discusses the authority of the Supreme Court and the Judicial Commission for the appointment of judges and considers the basis of independence of judicial power.
\end{abstract}

Keywords: Selection for Appointment of Judges; Independence; Judiciary; Judge; Supreme Court; Judicial Commission.

\begin{abstract}
Abstrak
Penelitian ini memiliki tujuan untuk menjelaskan seleksi pengangkatan hakim dalam sistem peradilan Indonesia yang dikaji berdasarkan putusan Mahkamah Konstitusi Nomor 43/PUU-XII/2015. Penelitian ini mengunakan metode pendekatan yuridis normatif dengan spesifik penelitian berdasarkan deskriptif analisis. Hakim memiliki peran penting dalam sistem peradilan di Indonesia, diharapkan seleksi pengangkatan hakim dilakukan oleh lembaga negara yang berwewenang, berdasarkan peraturan perundangundangan yang berlaku agar dapat menjamin independensi lembaga peradilan maupun independensi hakim. Penelitian ini membahas wewenang Mahkamah Agung dan Komisi Yudisial dalam pengangkatan hakim serta memperhatikan landasan akan kemerdekaan kekuasaan kehakiman.
\end{abstract}

Kata Kunci: Seleksi Pengangkatan Hakim, Independensi, Lembaga Peradilan, Hakim, Mahkamah Agung, Komisi Yudisial. 


\section{A. PENDAHULUAN}

Hakim sebagai pelaku utama secara fungsional dalam melaksanakan fungsi kekuasaan kehakiman, karena hakikatnya kekuasaan kehakiman memiliki pilar yang terdiri dari badan peradilan yang ditegakkan berdasarkan undangundang. Dalam melaksanakan fungsi kekuasaaan kehakiman, hakim harus memahami ruang lingkup tugas dan kewajiban sebagaimana telah diatur dalam perundang-undangan. Setelah memahami tugas dan kewajibannya, selanjutnya hakim harus berupaya secara profesional dalam menjalankan dan menyelesaikan pekerjaannya. ${ }^{1}$ Sehingga untuk mendapatkan hakim yang memiliki kriteria-kriteria yang memiliki integritas tinggi, disiplin, kepribadian yang tidak tercela, adil, profesional, maka proses seleksi hakim merupakan bagian penting, tanpa adanya proses seleksi pengangkatan hakim akan berdampak pada sistem peradilan yang tidak dapat mewujudkan keadilan dalam penegakan hukum.

Sebagai konstitusional UndangUndang Dasar 1945 menjabarkan 3(tiga) lembaga negara yang berkaitan dengan kekuasaan kehakiman yakni Mahkamah Agung, Mahkamah Konstintusi, dan Komisi Yudisial, secara struktural ketiga lembaga tersebut sejajar, sehingga tidak ada lembaga yang lebih rendah maupun yang lebih tinggi. Perbedaan lembaga yang terdapat dalam kekuasaan kehakiman yakni kedudukan Mahkamah Agung dan Mahkamah Konstitusi yang merupakan pelaksana fungsional dari kekuasaan kehakiman, sedangkan Komisi Yudisial merupakan lembaga pendukung (auxilary state organ) dari pelaksanaan kekuasaan kehakiman yang berkaitan dengan pengawasan etik terhadap hakim dan terdapat wewenang lainnya, yang diatur dalam perundang-undang lainnya.

Pelaksanaan kekuasaan kehakiman membutuhkan peran hakim, sehingga bagian penting dalam pelaksanaan kekuasaan kehakiman dalam seleksi pengangkatan hakim. Sebelum adanya lembaga negara Komisi Yudisial, seleksi pengangkatan hakim dilaksanakan oleh Mahkamah Agung, tetapi tidak berjalan maksimal karena kurangnya kepercayaan masyarakat pada sistem peradilan disebabkan adanya korupsi dan terdapatnya unsur politik dalam peradilan sehingga mengganggu prinsip dasar peradilan yang bersifat independen dan tidak diintervensi oleh pihak/lembaga negara lainnya.

Sehingga untuk meningkatkan kepercayaan masyarakat terhadap sistem peradilan di Indonesia, maka dibentuk Komisi Yudisial pada tahun 2001 terdapat pada Amandemen Ketiga UndangUndang Dasar 1945 Pasal 24 mengenai Kekuasaan Kehakiman, serta memberikan beberapa wewenang pada Komisi Yudisial. Wewenang tersebut diperluas pada Peraturan perundang-undangan lainnya. Seleksi pengangakatan hakim merupakan bagian dari kewenangan Komisi Yudisial yang pelaksanaannya dilakukan bersama dengan Mahkamah Agung.

Setelah disahkannya Amandenmen Ketiga Undang-Undang Dasar 1945, Seleksi pengangkatan hakim yang

1 Wildan Suyuthi Mustofa, Kode Etik Hakim, Kencana Prenadamedia Group, 2013, Jakarta, hlm. 105. 
merupakan bagian dari kewenangan Mahkamah Agung dan Komisi Yudisial, hal ini diatur selanjutnya dalam peraturan perundang-undangan yang lebih rendah. Akan tetapi pelaksanaan dari kewenangan ini tidak dapat berjalan dengan baik oleh Mahkamah Agung dan Komisi Yudisial, masih banyak terdapat faktorfaktor yang mempengaruhi kepentingan lembaga, bahkan mengakibatkan tidak terlaksanakannya seleksi pengangkatan hakim yang menimbulkan kesenjangan generasi hakim dalam sistem peradilan.

Oleh karena pelaksanaan kewenangan ini tidak berjalan dengan optimal karena terdapatnya bentrokan kepentingan antara Mahkamah Agung dan Komisi Yudisial, sehingga disusunlah Peraturan Bersama Mahkamah Agung dan Komisi Yudisial Nomor 01/P/MA/IX/201201/PB/P.KY/09/2012 tentang Seleksi Pengangkatan Hakim. Dengan adanya peraturan bersama ini diharapkan Mahkamah Agung dan Komisi Yudisial dapat melaksanakan kewenangan tersebut dengan optimal sesuai dengan peraturanperaturan yang ada serta dapat mencapai maksud dan tujuannya. Tetapi dengan adanya peraturan bersama tersebut, permasalahan antara Mahkamah Agung dan Komisi Yudisial tidak langsung dapat diselesaikan, hal ini dikarenakan tidak adanya penjabaran akan batasan-batasan kewenangan antara lembaga dalam seleksi pengangkatan hakim, sehingga semakin memperjelas bahwa permasalahan Mahkamah Agung dan Komisi Yudisial tidak hanya sekedar permasalahan wewenang, tetapi juga terdapat permasalahan kepentingan-kepentingan lainnya antar lembaga, hal ini harus ditinjau dari landasan-landasan dalam pembentukan lembaga negara tentang kekuasaan kehakiman. Dengan demikian dapat dipastikan bahwa Peraturan Bersama Mahkamah Agung dan Komisi Yudisial Nomor 01/P/MA/IX/201201/PB/P.KY/09/2012 tentang Seleksi Pengangkatan Hakim, tidakmemberikan solusi untuk penyelesaian permasalahan antara Mahkamah Agung dan Komisi Yudisial dalam hal seleksi pengangkatan hakim.

Persoalan tersebut masih menjadi pembahasan yang penting untuk pelaksanaan kekuasaan kehakiman. Masyarakat juga turut mengkritisi akan kewenangan Komisi Yudisial dalam seleksi pengangkatan hakim. Berbagai pendapat mengkhawatiran peran serta Komisi Yudisial dalam seleksi pengangkatan hakim mengganggu independensi lembaga Mahakamah Agung. Tetapi ada juga pendapat yang mendukung kedudukan Komisi Yudisial turut serta dalam seleksi pengangkatan hakim sebagaimana tujuan utama dari pembentukan Komisi Yudisial yakni meningkatkan kembali kepercayaan masyarakat kepada sistem peradilan yang dulunya sudah tercemar dengan korupsi, politik, dan nepotisme.

Dengan adanya permasalaham yang tidak kunjung dapat diselesaikan, maka adanya permohonan judicial rivew terhadap beberapa peraturan perundang-undangan yang menegaskan wewenang Komisi Yudisial dalam seleksi pengangkatan hakim, dan berdasarkan permohonan tersebut maka Mahkamah Konstitusi memberikan Putusan Nomor 43/PUU-XII/2015, yang memberikan putusan menghapuskan wewenang Komisi 
Yudisial dalam seleksi pengangkatan hakim.

Berdasarkan latar belakang di atas, maka yang menjadi rumusan masalah dalam penulisan ini yakni apakah Putusan Mahkamah Konstisusi Nomor 43/PUUXII/2015 sesuai dengan prinsip-pinsip dalam pelaksanaan kekuasaan kehakiman yang independen?

\section{B. PEMBAHASAN}

\section{Sistem Peradilan Di Indonesia}

SoerjonoSoekanto berpendapatbahwa suatu sistem merupakan keseluruhan terangkai, yang mencakup unsur, bagian, konsistensi, kelengkapan dan konsepsi atau pengertian dasarnya. ${ }^{2}$ Sedangkan menurut Lili Rasjidi yang menjadi ciri-ciri suatu sistem adalah: ${ }^{3}$

a. Suatu kompleksitas elemen yang terbentuk dalam satu kesatuan interaksi (proses);

b. Masing-masing elemen terikat dalam satu kesatuan hubungan yang satu sama lain saling bergantung (interdependence of its parts);

c. Kesatuan elemen yang kompleks itu membentuk satu kesatuan yang lebih besar, yang meliputi keseluruhan elemen pembentuknya itu (the whole is more than the sum of its parts);

d. Keseluruhan itu menentukan ciri dari setiap bagian pembentuknya (the whole determines the nature of its parts); e. Bagian dari keseluruhan itu tidak dapat dipahami jika ia dipisahkan, atau dipahami secara terpisah dari keseluruhan itu (the parts cannot be understood if considered in isolation from the whole);

f. Bagian-bagian itu bergerak secara dinamis, secara mandiri atau secara keseluruhan dalam keseluruhan (sistem) itu.

Pemahaman akan peradilan dengan membedakan antara peradilan dengan pengadilan. Menurut Bernard Arief Sidharta yang dikutip oleh Dudu Duswara Machmudin ${ }^{4}$ menyatakan bahwa peradilan merupakan institusi, pranata dan proses. Sedangkan pengadilan merupakan lembaga, organisasi, struktur dan badan peradilan. Peradilan adalah pranata untuk memberikan definitif terhadap sesuatu sengketa atau perkara (antar warga-mayarakat, atau antara warga masyarakat dan pemerintah) atau masalah kemasyarakatan konkrit secara imparsial-objektif dan adil manusiawi dalam kerangka dan berdasarkan tatanan hukum positif yang berlaku. Secara imparsial berarti proses dan penetapan putusan penyelesaian terhadap sengketa itu dilakukan oleh lembaga yang tidak memihak, yakni oleh hakim atau majelis hakim sebagai pejabat pengadilan yang mengemban tugas utama untuk melaksanakan fungsi peradilan dari pengadilan. Oleh karena itu, hakim dalam melaksanakan peran pada sistem

2 Soerjono Soekanto, Penegakan Hukum, Binacipta, Jakarta, 1983, hlm. 2.

3 Lili Rasjidi dan I.B. Wiyasa Putra, Hukum Sebagai Suatu Sistem, Remaja Rosdakarya, Bandung, 1993, hlm. 43-44.

4 Dudu Duswara Mahcmudin, Kedudukan dan Peran Pengadilan Tindak Pidana Korupsi Dalam Sistem Peradilan Pidana Indonesia, Disertasi Universitas Katolik Parahyangan, Bandung, 2010, hlm. 40. 
peradilan menjadi unsur terpenting dalam menjalankan fungsi kekuasaan kehakiman.

Setelah membedakan makna peradilan dengan pengadilan menurut Sacipto Rahardjo menyebutkan bahwa sesungguhnya lembaga peradilan adalah tempat untuk menyelesaikan persoalanpersoalan hukum agar tidak berkembang menjadi konflik yang membahayakan keamanan dan ketertiban masyarakat. ${ }^{5}$ Kekuasaan kehakiman dan peradilan merupakan kekuasaan yang diberikan untuk memeriksa dan mengadili serta memberikan putusan atas perkaraperkara yang diserahkan kepadanya dengan tujuan untuk menegakkan hukum dan keadilan, kemudian menurut Abdul Mukhti Fajar yang dikutip oleh Taufik Sukasah, ciri-ciri lembaga peradilan yaitu: ${ }^{6}$

a. Merupakan lembaga independen atau lembaga yang bebas dari kekuasaan lembaga lain baik secara fungsional maupun struktural;

b. Adanya hukum yang bersifat umum yang merupakan sumber hukum yang akan diterapkanoleh lembaga peradilan;

c. Adanya pihak yang bersengketa yang mempunyai kepentingan secara langsung atas putusan yang disengketakan yang dapat memberikan dasar bagi pemberian status untuk mengajukan gugatan atau permohonan;

d. Adanya perkara konkrit yang terjadi yang diajukan untuk mendapatkan putusan; e. Keputusan lembaga mempunyai sifat eksekutorial, tanpa perlunya persetujuan penuh dari lembaga lain.

Susunan sistem peradilan Indonesia terdiri dari Mahkamah Konstitusi, Mahkamah Agung, Peradilan yang dibawahnya terdapat Peradilan Umum (Pengadilan Negeri, Pengadilan Tinggi, pengadilan khusus yang terdiri dari Pengadilan Anak, Pengadilan Niaga, Pengadilan Tindak Pidana Korupsi, Pengadilan Hubungan Industrial, Pengadilan Pajak). Peradilan Agama (Pengadilan Agama dan Pengadilan Tinggi Agama), Peradilan Militer (Pengadilan Militer Dan Pengadilan Tinggi Militer) dan Peradilan Tata Usaha Negara (Pengadilan Tata Usaha Negara Dan Pengadilan Tinggi Tata Usaha Negara).

Pelaksanaan sistem peradilan Indonesia yang terdiri dari peran kekuasaan kehakiman yang diberikan UndangUndang Dasar 1945, pelaksanaan yang saling koordinasi antara lembaga untuk pencapaian tujuan bangsa sebagai negara hukum. Sistem peradilan diamanatkan dan dikehendaki oleh konstitusi dalam melaksanakan kekuasaan kehakiman, yang tugasnya tidak sekedar menegakkan hukum, tetapi sekaligus menegakkan keadilan telah terpenuhi. Dengan sistem dan mekanisme yang tertata maka pencari keadilan telah dilindungi untuk mendapatkan hakim yang bebas dan tidak memihak. Serta mempertahankan prinsip peradilan yang bebas dan mandiri, peradilan tanpa membedakan orang,

$5 \quad$ Satjipto Rahardjo, Hukum dan Perubahan Sosial, Penerbit Alumni, Bandung, 1986, hlm. 107.

6 Taufik Sukasah, Profil Lembaga Negara Rumpun Yudikatif, Asisten Deputi Hubungan Lembaga Negara dan Lembaga non-Sturktural Deputi Hubungan Bidang Kelembagaan dan Kemasyarakatan Kementerian Sekretaris Negara Republik Indonesia, Jakarta, 2012, hlm. 13. 
merupakan sendi negara hukum yang demokratis sesuai yang dikehendaki oleh UUD 1945.

\section{Kekuasaan Kehakiman}

Perubahan hukum yang terjadi melalui Amandemen Ketiga UndangUndang Dasar 1945 yang mengakibatkan terjadinya perubahan terhadap struktur kekuasaan kehakiman. Sebelum terjadinya perubahan ini menunjukkan Mahkamah Agung berperan tunggal sebagai pelaksana kekuasaan kehakiman, tetapi setelah Amandemen Ketiga Undang-Undang Dasar 1945, kekuasaan kehakiman tidak hanya dilaksanakan oleh Mahkamah Agung melainkan terdapat juga Mahkamah Konstitusi.Pengaturan Kekuasaan Kehakiman terdapat pada:

Pasal 24 ayat 1 UUD 1945:

"Kekuasaan kehakiman merupakan kekuasaan yang merdeka untuk menyelenggarakan peradilan guna menegakkan hukum dan keadilan."

Pasal 24 ayat (2) UUD 1945:

"Kekuasaan kehakiman dilakukan oleh sebuah Mahkamah Agung dan badan peradilan yang berada di bawahnya dalam lingkungan peradilan umum, lingkungan peradilan agama, lingkungan peradilan militer, lingkungan peradilan tata usaha negara, dan oleh sebuah Mahkamah Konstitusi."

Kekuasaan kehakiman memiliki pengertian adanya kebebasan dari campur tangan pihak kekuasaan lainnya, dan kebebasan dari paksaan, diretiva dan rekomendasi yang datang dari pihak ekstra yudisial dalam hal-hal yang diizinkan Undang-Undang. Pemahaman akan kekuasaan kehakiman memiliki beberapa tujuannya berdasarkan pandangan Bagir Manan ${ }^{7}$ yang ingin dicapai dengan kekuasaan kehakiman yang merdeka yakni:

a. Sebagai bagian dari sistem pemisahan atau pembagian kekuasaan diantara badan-badan penyelenggaraan negara, kekuasaan kehakiman diperlukan untuk menjamin dan melindungi kebebasan individu;

b. Kekuasaan kehakiman yang merdeka diperlukan untuk mencegah penyelenggara pemerintahan bertindak sewenang-wenang dan menindas;

c. Kekuasaan kehakiman yang merdeka diperlukan untuk menilai keabsahan suatu peraturan perundang-undangan sehingga sistem hukum dapat dijalankan dan ditegakkan dengan baik.

Menurut putusan Mahkamah Konstitusi 005/PUU-IV/2006 yang dimaksud kemerdekaan kekuasaan kehakiman yakni kemerdekaan yang tidak pernah diartikan mengandung sifat mutlak, karena dibatasi oleh hukum dan keadilan. Kemerdekaan hakim tersebut bukan merupakan previlege atau hak istimewah hakim, melainkan merupakan hak yang melekat (indispensable right atau inherent right) pada hakim dalam rangka menjamin pemenuhan hak asasi dari warga

$7 \quad$ Bagir Manan, Kekuasaan Kehakiman Republik Indonesia, LPPM Universitas Islam Bandung, 1995, hlm. 64. 
negara untuk memperoleh peradilan yang bebas dan tidak berpihak (fair trial). Independensi peradilan yang disinggung tersebut adalah independensi peradilan dalam segala ranahnya, baik independensi konstitusional, independensi personal, independensi peraturanyangmengaturnya dan independensi substantif.

Kekuasaan kehakiman yang merdeka juga diartikan sebagai pelaksana peradilan yang bebas dan tidak memihak yang dilakukan oleh hakim untuk menyelesaikan berbagai masalah hukum yang diajukan kepengadilan. Kekuasaan kehakiman yang merdeka ini merupakan elemen mutlak yang harus ada didalam sebuah negara yang berpredikat negara hukum. ${ }^{8}$ Memiliki tujuan untuk menjamin kebebasan individu, pencegahan tindakan pemerintah yang sewenang-wenang dengan mendasarkan pada negara hukum.

Menurut Monteque yang dikutip oleh Andi M. Masrum ${ }^{9}$ mengemukakan pentingnya kekuasaan yudikatif karena kekuasaan kehakiman yang independen of judiciary akan menjamin kebebasan individu dan hak asasi manusia. Prinsip persamaan dimuka hukum merupakan elemen yang penting dalam konsep rule of law yang selanjutnya Monteque mengatakan bahwa kebebasanpun tidak ada jika kekuasaan kehakiman tidak terpisahkan dari kekuasaan legislatif dan kekuasaan eksekutif. Jika kekuasaan kehakiman disatukan dengan kekuasaan legislatif, kekuasaan atas kehidupan dan kebebasan warga negara akan dijalankan sewenang-wenang karena hakim akan menjadi pembuat hukum. Jika kekuasaan kehakiman disatukan dengan kekuasaan eksekutif, hakim bisa menjadi penindas, yang perlu digaris bawahi adalah kemandirian kekuasaan kehakiam tidak saja mandiri secara lembaga, tetapi juga kemandirian dalam proses peradilan yang diidentifikasikan dari proses pemeriksaan perkara, pembuktian, hingga pada vonis yang dijatuhkan. Parameter mandiri atau tidaknya proses peradilan ditandai oleh ada atau tidaknya intervensi dari pihakpihak lain dari luar kekuasaan kehakiman.

Pemahaman akan kekuasaan kehakiman tidak terlepas dari lembaga negara Mahkamah Agung, Mahkamah Konstitusi, dan Komisi Yudisial. Ketiga lembaga negara yang disebutkan dalam UUD 1945 pada kekuasaan kehakiman yang tidak menjabarkan secara tegas dan rinci wewenang lembaga negara sehingga dibutuhkan peraturan perundangundangan dalam pelaksanaan wewenang dari lembaga tersebut.

Mahkamah Agung sebagai lembaga negara pertama dalam kekuasaan kehakiman dalam melaksanakan tugasnya berdasarkan Undang-Undang Nomor 14 Tahun 1985 tentang Mahkamah Agung, kemudian terjadi perubahan khususnya yang menyangkut pengawasan hakim, sudah tidak sesuai lagi dengan perkembangan kebutuhan hukum masyarakat dan ketatanegaraan menurut Undang-Undang Dasar 1945, maka dibentuk Undang Nomor 5 Tahun 2004

$8 \quad$ C.S.T. Kansil dan Christine ST Kansil, Hukum Tata Negara RI Jilid I, Rineka Cipta, Jakarta, 1984, hlm. 191192.

9 Andi M. Masrum, Krisis Peradilan Mahkamah Agung di Bawah Soeharto, Elsam, Jakarta, 2004, hlm. 32. 
tentang Perubahan Atas Undang-Undang Nomor 14 Tahun 1985 tentang Mahkamah Agung, dan selanjutnya atas perkembangan pelaksanaan kekuasaan kehakiman pada Mahkamah Agung sehingga terjadi perubahan yakni Undang-Undang Nomor 3 Tahun 2009 tentang Perubahan Kedua Atas Undang-Undang Nomor 14 Tahun 1985 tentang Mahkamah Agung.

Kekuasaan kehakiman yang juga dilaksanakan oleh Mahkamah Konstitusi sebagai lembaga negara yang berfungsi untuk menangani perkara tertentu dibidang ketatanegaraan, dalam rangka menjaga konstitusi agar dilaksanakan secara bertanggung jawab. Keberadaan Mahkamah Konstitusi sekaligus untuk menjaga terselenggaranya pemerintahan negara yang stabil. Mahkamah Konstitusi merupakan salah satu pelaku kekuasaan kehakiman yang terkait pada prinsip umum penyelenggaraan kekuasaan kehakiman yang merdeka, bebas dari pengaruh kekuasaan lembaga lainnya dalam menegakkan hukum dan keadilan.

Mahkamah Konstitusi sebagaimana telah disebutkan dalam Amandemen Ketiga Undang-Undang Dasar 1945, dalam pelaksanaan dibentuk Undang-Undang Nomor 24 Tahun 2003 Tentang Mahkamah Konstitusi, dan kemudian adanya perubahan unsur-unsur perundangundangan misalkan pada pengawasan hakim, oleh karena itu dibentuk UndangUndang Nomor 8 Tahun 2011 tentang Perubahan Atas Undang-Undang Nomor 24 tentang Mahkamah Konstitusi.

Kedudukan Komisi Yudisial menjadi suatu lembaga negara yang memiliki pengaruh kuat terhadap kekuasaan kehakiman terhadap pengawasan hakim,
Komisi Yudisial semakin tegas dalam kelembagaan negara dengan disahkannya Undang-Undang Nomor 22 Tahun 2004 tentang Komisi Yudisal, yang menjabarkan beberapa bagian tugas dan wewenang dari Komisi Yudisial sebagai sebuah lembaga negara yang berkaitan dibidang peradilan. Tetapi tidak dengan mudahnya suatu lembaga dapat melaksanakan tugasnya terdapat beberapa perubahan yang terjadi pada Undang-Undang Nomor 22 Tahun 2004 tentang Komisi Yudisial, sehingga disahkannya Undang-Undang Nomor 18 Tahun 2011 tentang Perubahan atas Undang-Undang Nomor 22 Tahun 2004 tentang Komisi Yudisial, perubahan mendasar yakni memberikan wewenang baru bagi Komisi Yudisial, antara lain untuk melakukan seleksi pengangkatan hakim adhoc di Mahkamah Agung, melakukan upaya peningkatan kapasitas dan kesejahterahan hakim, melakukan langkah-langkah hukum dan langkahlangkah lain untuk menjaga kehormatan, keluhuran martabat, serta perilaku hakim, melakukan penyadapan bekerja sama dengan aparat penegak hukum, dan melakukan pemanggilan paksa terhadap saksi.

Mahkamah Agung, Mahkamah Konstitusi dan Komisi Yudisial memiliki hubungan dan keterikatan dalam pelaksanaan kekuasaan kehakiman, dengan memperhatikan fungsi dan kedudukan lembaga sesuai dengan peraturan perundang-undangan yang berlaku, antara lain:

a. Mahkamah Agung merupakan lembaga kekuasaan kehakiman dan peradilan dibawah Mahkamah Agung serta Mahkamah Konstitusi. 
Mahkamah Agung melakukan pengawasan internal terhadap badan peradilan dalam lingkungan peradilan umum, lingkungan peradilan agama, lingkungan peradilan militer, lingkungan peradilan tata usaha negara. Akan tetapi Mahkamah Agung bukan satu-satunya lembaga negara yang melakukan pengawasan tersebut karena adanya pengawasan eksternal yang dilakukan oleh Komisi Yudisial.

b. Posisi Mahkamah Konstitusi seakan nampak lebih tinggi dibandingkan lembaga negara lainnya ketika memutuskan konstitusionalitas dari suatu ketentuan undangundang, demikian juga sengketa kewenangan antarlembaga negara. Walaupun demikian sesungguhnya dalam sturktur ketatanegaraan RI, posisi Mahkamah Konstitusi sejajar dengan lembaga negara yang lainnya dengan kewenangan yang secara limitatif diberikan UUD 1945. Karena Mahkamah Konstitusi bersama Mahkamah Agung dan badan peradilan dibawahnya Mahkamah Agung sebagai pelaksana fungsi kekuasaan kehakiman

c. Komisi Yudisial secara struktural kedudukannya sederajat dengan Mahkamah Agung dan Mahkamah Konstitusi, namun karena memiliki fungsi yang khusus dan penunjang (auxiliary), kedudukan protokolernya tidak perlu diperlakukan sama dengan Mahkamah Agung, Mahkamah Konstitusi, DPR, MPR, DPD, dan BPK. Karena, Komisi Yudisial itu sendiri bukan lembaga negara yang menjalankan fungsi kekuasaan negara secara langsung. Komisi Yudisial bukan lembaga yudikatif, eksekutif, apalagi legislatif. Komisi ini berfungsi mendukung untuk tegaknya kehormatan, keluhuran martabat, dan perilaku hakim sebagai pejabat penegak hukum dan lembaga yang menjalankan fungsi kekuasaan kehakiman (judiciary).

Dengan demikian, secara ringkas menjelaskan bahwa, dalam menjalankan fungsi kekuasaan kehakiman UUD 1945 menyebutkan bahwa ada tiga lembaga negara yang termasuk dalam ruang lingkup kekuasaan kehakiman, yaitu Mahkamah Agung, Mahkamah Konstitusi, dan Komisi Yudisial. Menurut Pasal 24 ayat (2) hanya Mahkamah Agung dan badan peradilan dibawahnya serta Mahkamah Konstitusi yang merupakan penyelenggara kekuasaan kehakiman, sedangkan Komisi Yudisial tidak memiliki kewenangan tersebut, sehingga badan ini sering disebut sebagai lembaga ekstrayudisial dengan menjalankan fungsi yang khusus dan penunjang (auxiliary). Dengan demikian peradilan sebagai pelaksana kekuasaan kehakiman merupakan unsur penting dalam sebuah negara yang berdasarkan hukum dengan unsur kriteria mandiri (independent), netral (impartiality), dan kompeten sebagaimana diatur dalam UUD 1945.

\section{Kajian Putusan Mahkamah Konstitusi Nomor 43/PUU-XII/2015} Kebebasan atau kemerdekaan diberikan kepada institusi pelaku kekuasaan kehakiman yang ada pada Mahkamah Agung berserta badan-badan peradilan dibawah Mahkamah Agung, 
dan Mahkamah Konstitusisesuai dengan Pasal 24 ayat (2) UUD 1945, bertujuan untuk menyelenggarakan peradilan guna menegakkan hukum dan keadilan. Kebebasan atau kemerdekaan institusional pada lembaga peradilan dengan sendirinya tercermin dalam kebebasan para hakim sebagai pelaku kekuasaan kehakiman. Dengan deminkian jelas jika hakimmerupakanbagian integral dari sistem kekuasaan kehakiman dan proses seleksi pengangkatan hakim merupakan faktor penting yang ikut menentukan berjalan atau tidaknya sistem peradilan. Oleh karenaitu jelas bahwa tanpa proses seleksi pengangkatan hakim yang merdeka dan mandiri, maka peningkatan sistem peradilan guna menegakkan hukum dan keadilan akan sulit dilaksanakan.

Kewenangan Mahkamah Agung dalam seleksi pengangkatan hakim tidak terdapat secara langsung dan tegas pada UUD 1945 melainkan terdapat pada Pasal 21 ayat (1) Undang-Undang 48 Tahun 2009 tentang Kekuasaan Kehakiman, yang menyatakan:

"Organisasi, administrasi, finansial mahkamah agung dan badan peradilan yang berada dibawahnya berada dibawah kekuasaaan mahkamah agung,sedangkan ayat (2) berbunyi ketentuan mengenai organisasi, administrasi, dan finansial badan peradilan sebagaimana dimaksud pada ayat (1) untuk masing-masing lingkungan peradilan diatur dalam undang-undang sesuai dengan kekhususan lingkungan peradilan masing-masing."

Hal yang sama pada Komisi Yudisial, kewenangan dalam hal seleksi pengangkatan hakim tidak disebutkan pada UUD 1945, karena Pasal 24B ayat (1) UUD 1945 yang menyatakan bahwa:

"Komisi Yudisial bersifat mandiri yang berwenang mengusulkan pengangkatan hakim agung dan mempunyai kewenangan lain dalam rangka menjaga dan menegakkan kehormatan, keluhuran martabat, serta perilaku hakim."

Kewenangan seleksi pengangkatan hakim tidak secara tegas disebutkan dalam UUD 1945 terhadap Mahkamah Agung begitu juga dengan Komisi Yudisial. Mahkamah Agung dan Komisi Yudisial berwenang untuk seleksi pengangkatan hakim sebagaimana dalam perundangundangan dibawah ini:

a. Undang-Undang Nomor 49 Tahun 2009 tentang Perubahan Kedua Atas Undang-Undang Nomor 2 Tahun 1986 tentang Peradilan Umum, pada Pasal 14A ayat (2) dan (3) yang berbunyi:

(2) proses seleksi pengangkatan hakim pengadilan negeri dilakukan bersama oleh mahkamah agung dan komisi yudisial

(3) ketentuan lebih lanjut mengenai proses seleksi diatur bersama oleh mahkamah agung dan komisi yudisial.

b. Undang-undang Nomor 50 Tahun 2009 tentang Perubahan Kedua Atas Undang-Undang nomor 7 Tahun 1989 tentang Peradilan Agama, Pasal 13A ayat (2) dan ayat (3) yang berbunyi:

(2) Proses seleksi pengangkatan hakim pengadilan agama dilakukan bersama oleh Mahkamah Agung dan Komisi Yudisial. 
(3) ketentuan lebih lanjut mengenai proses seleksi diatur bersama oleh mahkamah agung dan komisi yudisial.

c. Undang-Undang Nomor 51 Tahun 2009 tentang Perubahan Kedua Atas Undang-Undang Nomor 5 Tahun 1986 tentang Peradilan Tata Usaha Negara, Pasal 14A ayat (2) dan ayat (3) yang berbunyi :

(2) proses seleksi pengangkatan hakim pengadilan negeri dilakukan bersama oleh mahkamah agung dan komisi yudisial

(3) ketentuan lebih lanjut mengenai proses seleksi diatur bersama oleh mahkamah agung dan komisi yudisial.

Akan tetapi dalam pelaksanaannya tidak dengan mudah untuk diterapkan oleh Mahkamah Agung dan Komisi Yudisial mengenai seleksi pengangkatan hakim. Pada tahun 2010, Mahkamah Agung telah melakukan seleksi hakim tanpa melibatkan Komisi Yudisial sehingga untuk menyelamatkan/melegalkan calon hakim yang terlanjur diterima melalui seleksi pengangkatan hakim yang diselenggarakan Mahkamah Agung dibuatlah Peraturan bersama Mahkamah Agung dan Komisi Yudisial Nomor 01/P/ MA/IX/2012-01/PB/P.KY/0 9/2012 tentang Seleksi Pengangkatan Hakim.

Berdasarkan Peraturan Bersama Mahkamah Agung dan Komisi Yudisial Nomor 01/P/MA/IX/2012-01/PB/P.KY/ 09/2012 tentang Seleksi Pengangkatan Hakim. Mahkamah Agung dan Komisi Yudisial menyepakati metode rekrutmen, bahwa rekrutmen dilakukan oleh Mahkamah Agung dan Komisi Yudisial dengan mengacu hakim sebagai pejabat negara, dengan penjabaran tata cara seleksi dan pembiayaan. Seleksi pengangkatan hakim yang rangkaian proses mulai dari pendidikan calon hakim terpadu, sampai pada penentuan akhir untuk diangkat menjadi hakim. Demikian pula bahwa peraturan bersama Mahkamah Agung dan Komisi Yudisial tidak memberikan secara tegas pembagian kewenangan antara Mahkamah Agung dan Komisi Yudisial dalam seleksi pengangkatan hakim sehingga banyak menimbulkan penafsiran yang berbeda.Sehingga semakin mempertegas bahwa pembagian kewenangan seleksi pengangkatan hakim antara Mahkamah Agung dan Komisi Yudisial tidak disebutkan dalam peraturan yang terkait,

Maka secara ringkas dapat disimpulkan bahwa dengan tidak adanya penyebutan secara tegas pembagian batasan kewenangan Mahkamah Agung dan Komisi Yudisial dalam seleksi pengangkatan hakim dalam Undang-Undang Dasar 1945. Melainkan penjabaran mengenai seleksi pengangakatan hakim dalam peraturan perundang-undangan dan peraturan pelaksana lainnya bahwa Mahkamah Agung dan Komisi Yudisial berwenang dalam seleksi pengangkatan hakim. Dan pelaksanaan seleksi pengangkatan hakim dilakukan berdasarkan Peraturan bersama Mahkamah Agung dan Komisi Yudisial Nomor 01/P/MA/IX/201201/PB/P.KY/09/2012 tentang Seleksi Pengangkatan Hakim. Walaupun tidak dengan mudah dapat dilaksanakan bahkan tidak dapat diterapkan oleh karena tidak jelasnya pembagian kewenangan Mahkamah Agung dan Komisi Yudisial.

Dengan memperhatikan dasar-dasar hukum yang telah dijabarkan diatas akan 
seleksi pengangkatan hakim, maka kajian selanjutnya yakni alasan-alasan pemohon yang mewakili IKAHI (Ikatan Hakim Indonesia) untuk judicial review atas kewenangan Komisi Yudisial dalam seleksi pengangkatan hakim yakni:

a. Keterlibatan Komisi Yudisial dalam proses seleksi pengangkatan hakim pada Peradilan Umum,Peradilan Agama, dan Peradilan Tata Usaha Negara adalah inkonstitusional, karena bertentangan dengan Pasal 24 ayat (1), Pasal 24B ayat (1), dan Pasal 28D ayat (1) UUD 1945, hal ini bertentangan pula dengan prinsip hukum yang berlaku secara universal yakni:

1) Prinsip lex certa adalah suatu materi dalam peraturan perundang-undangan tidak dapat diperluas atau ditafsirkan lain selain ditulis dalam peraturan perundang-undangan.

2) Prinsip lex stricta merupakan suatu ketentuan atau perundangundangan tidak dapat diberikan perluasan selain ditentukan secara tegas dan jelas menurut peraturan perundang-undangan.

3) Prinsip lex superior derogate legi inferiori yakni suatu perundangundangan yang lebih rendah tidak boleh bertentangan dengan peraturan perundang-undangan yang lebih tinggi.

a. Kekuasaan Kehakiman yang merdeka tidakhanya dalamkonteks pelaksanaan kewenangan hakim dalam memeriksa, mengadili, dan memutus perkara. Melainkan juga untuk melakukan proses seleksi dan perekrutan hakim yang berkualitas secara independen dan mandiri. Dengan berlakunya pasal a quo akan dapat menjadi pintu masuk bagi intervensi suatu lembaga terhadap lembaga lain yang akan merusak mekanisme checks and balances yang dibangun. Adanya keterlibatan Komisi Yudisial dalam seleksi pengangkatan hakim pada Peradilan Umum, Peradilan Agama, dan Peradilan Tata Usaha Negara, akan merusak sistem kekuasaan kehakiman yang dijamin oleh konstitusi karena adanya segala campurtangan dalam urusan peradilan oleh pihak lain diluar kekuasaan kehakiman dilarang, kecuali dalam hal-hal sebagaimana dimaksud dalam UUD 1945.

b. Rumusan menyangkut keterlibatan Komisi Yudisial dalam proses seleksi pengangkatan hakim, sebagaimana yang tercantum dalam ketentuan pasal-pasal a quo, menimbulkan implikasi ketidakpastian hukum dan menimbulkan persoalan konstitusionalitas.

Berdasarkan alasan-alasan di atas, maka berbagai pendapat para ahli yang mendukung maupun tidak mendukung, yang menjadi bahan pertimbangan oleh Mahkamah Konstitusi dalam memberikan putusan yang berdasarkan UndangUndang Dasar 1945. Mahkamah konstitusi memberikan putusan dengan menyatakan:

a. Undang-Undang Nomor 49 Tahun 2009 tentang Perubahan Kedua Atas Undang-Undang Nomor 2 Tahun 1986 tentang Peradilan Umum , pada Pasal 14A ayat (2) dan (3).

b. Undang-Undang Nomor 50 Tahun 2009 tentang Perubahan Kedua Atas 
Undang-Undang Nomor 7 Tahun 1989

tentang Peradilan Agama, pada Pasal $13 \mathrm{~A}$ ayat (2) dan ayat (3).

c. Undang-Undang Nomor 51 Tahun 2009 tentang Perubahan Kedua Atas Undang-Undang Nomor 5 Tahun 1986 tentang Peradilan Tata Usaha Negara, pada Pasal 14A ayat (2) dan ayat (3).

Peraturan perundang-undangan yang disebutkan diatas bertentangan dengan UUD 1945, dan tidak memiliki kekuatan hukum mengikat. Sehingga, proses seleksi pengangkatan hakim Peradilan Umum, Peradilan Agama, dan Peradilan Tata Usaha Negara.Ketentuan lebih lanjut mengenai proses seleksi diatur oleh Mahkamah Agung.Berdasarkan penjabaran di atas, maka kajian akan seleksi pengangkatan hakim yang berdasarkan Putusan Mahkamah Konstitusi Nomor 43/ PUU-XII/2015, maka akan dijabarkan keterkaitan pada independen kekuasaan kehakiman dalam seleksi pengangkatan hakim.

Makna independensi kekuasaan kehakiman yang merdeka. Kemerdekaan yang dimaksud tidak mengandung sifat mutlak, karena dibatasi oleh hukum dan keadilan. Kemerdekaan untuk hakim dalam melaksanakan kekuasaan kehakiman tersebut bukan merupakan hak istimewahakim melainkan hak yang melekat pada hakim dalam rangka melaksanakan kewajibannya untuk mencapai tujuan sebagaimana dimaksud pada UUD 1945. Sehingga dengan adanya lembaga lain dalam kekuasaan kehakiman tidak menjadi masalahasalkan masih pada batasan yang tidak menyangkut materi kekuasaan kehakiman.
Komisi Yudisial sebagai lembaga yang berperan dalan fungsi kekuasaan kehakiman. Komisi Yudisial yang memiliki kewenangan dalam pengawasan kode etik hakim dalam melaksanakan kewajibannya. Adanya lembaga pengawasan eksternal yang diberikan tugas menjalankan fungsi checks and balances dalam rangka mengawasi peradilan diharapkan berjalan dengan transparan, akuntabel, dan imparsial, serta mengedepankan aspek kepastian, keadilan, dan kemanfaatan. Komisi Yudisial yang bersifat mandiri dalam pelaksanaan wewenangnya bebas dari campur tangan atau pengaruh kekuasaan lainnya.

Pemberian kewenangan kepada Komisi Yudisial untuk mengikuti pengangkatan hakim bersama Mahkamah Agung justru dimaksudkan untuk membangun semakin kokohnya kemerdekaan kekuasaan kehakiman tersebut. Pemberian kewenangan kepada Komisi Yudisial untuk ikut melakukan proses seleksi pengangkatan hakim bersama Mahkamah Agung justru dimaksudkan agar bisa terpilih dan tampil hakim, yakni hakimyang mempunyai integritas, berani, dan bersih. Sebagai hakim sesuai dengan pilihan yang sama antara Mahkamah Agung dan Komisi Yudisial. Setelah seseorang menjadi hakim maka tidak ada hubungan struktural dan administratif antara Komisi Yudisial dengan hakim-hakim tersebut.

Pelaksanaan seleksi pengangkatan hakim yang dilakukan oleh Mahkamah Agung dan Komisi Yudisial merupakan sesuatu yang baik berdasarkan prinsip check and balances, untuk menghasilkan pilihan yang tepat, yang lebih objektif dengan memenuhi kriteria-kriteria dan 
syarat-syarat yang objektif pada pilihan hakim yang berintegritas dan kepribadian yang tidak tercela, adil, profesional, dan pengalaman dibidang hukum sehingga mencapai dari tujuan yang telah diamanatkan oleh Undang-Undang Dasar 1945.

Putusan Mahkamah Konstitusi nomor 43/PUU-XII/2015 mengembalikan bentuk seleksi pengawasan hakim sebagaimana sebelum terbentuknya komisi yudisial yang terdapat dalam amandemen ketiga Undang-Undang Dasar 1945. Kewenangan sepenuhnya dalam pelaksanaan seleksi pengangkatan hakim ada pada Mahkamah Agung.

\section{PENUTUP}

\section{Kesimpulan}

Konsep kekuasaan kehakiman yang independen ditegaskan kembali dalam Putusan Mahkamah Konstisusi Nomor 43/PUU-XII/2015, lembaga negara Mahkamah Agung dan badan peradilan yang berada di bawahnya dalam lingkungan Peradilan Umum, lingkungan Peradilan Agama, lingkungan Peradilan Militer, lingkungan Peradilan Tata Usaha Negara, dan Mahkamah Konstitusi. Akan tetapi keterlibatan Komisi Yudisial dalam proses seleksi pengangkatan hakim Pengadilan Negeri, hakim Pengadilan Agama, Dan hakim Pengadilan Tata Usaha Negara yang dilakukan bersama-sama dengan Mahkamah Agung tidaklah mengganggu administrasi, organisasi, maupun finansial pengadilan sepanjang keterlibatan Komisi Yudisial dalam memberikan pemahaman kode etik dan pedoman perilakuhakim bagi calon hakim yang telah dinyatakan lulus dalam proses seleksi sebagai calon pegawai negeri sipil. Pelaksanaan Seleksi Pengangkatan Hakim setelah putusan Mahkamah Konstitusi Nomor 43/PUU-XII/2015 memutuskan untuk mengembalikan bentuk seleksi pengawasan hakim sebagaimana sebelum terbentuknya Komisi Yudisial yang terdapat dalam Amandemen Ketiga Undang-Undang Dasar 1945 yakni kewenangan seleksi pengangkatan hakim ada pada Mahkamah Agung.

\section{Saran}

a. Menguatkan hubungan lembaga negara Mahkamah Agung dan badan peradilan yang berada di bawahnya dalam lingkungan Peradilan Umum, lingkungan peradilan agama, lingkungan Peradilan Militer, lingkungan Peradilan Tata Usaha Negara, dan Mahkamah Konstitusi terhadap Komisi Yudisial dalam menjalankan kewenangan untuk mencapai maksud dan tujuan dari UUD 1945 dengan cara melakukan koordinasi antar lembaga negara.

b. Pelaksanaan seleksi pengangkatan hakim dengan jujur, transparan, dan akuntable tanpa unsur Korupsi, Kolusi, dan Nepotisme. Sehingga mendapatkan calon hakim sesuai kriteria dan mendapatkan kepercayaan masyarakat terhadap sistem hukum di Indonesia. 


\section{DAFTAR PUSTAKA}

\section{Buku:}

Andi M. Masrum, Krisis Peradilan Mahkamah Agung di Bawah Soeharto, Jakarta: Elsam, 2004.

Bagir Manan, Kekuasaan Kehakiman Republik Indonesia, Bandung: LPPM Universitas Islam Bandung, 1995.

C.S.T. Kansil dan Christine ST Kansil, Hukum Tata Negara RI Jilid I, Jakarta: Rineka Cipta, 1984.

Dudu Duswara Mahcmudin, Kedudukan dan Peran Pengadilan Tindak Pidana Korupsi Dalam Sistem Peradilan Pidana Indonesia, Bandung: Disertasi Universitas Katolik Parahyangan, 2010.

Lili Rasjidi dan I.B. Wiyasa Putra, Hukum Sebagai Suatu Sistem, Bandung: Remaja Rosdakarya, 1993.

Sacipto Rahardjo, Hukum dan Perubahan Sosial, Bandung: Penerbit Alumni, 1986.

Soerjono Soekanto, Penegakan Hukum, Jakarta: Binacipta, 1983.

Taufik Sukasah, Profil Lembaga Negara Rumpun Yudikatif, Asisten Deputi Hubungan Lembaga Negara dan Lembaga non-Sturktural, Jakarta: Deputi Hubungan Bidang Kelembagaan dan Kemasyarakatan Kementerian
Sekretaris Negara Republik Indonesia, 2012.

Wildan Suyuthi Mustofa, Kode Etik Hakim, Jakarta: Kencana Prenadamedia Group, 2013. 